\title{
Police interrogations through the prism of science
}

Faculty of Criminal Justice and Security, University of Maribor, Slovenia

\begin{abstract}
Several approaches can be employed for information gathering from human sources, differing in their theoretical basis, goals, realisation, and ethical acceptability. The paper critically presents and compares two prevalent approaches to suspect interrogation used by the police. The older, prevalent interrogation approach focuses on obtaining suspects' incriminating statements and admissions, which severely elevates the risk of false confessions. Consequently, this interrogation approach is termed accusatorial or coercive since suspects are forced to admit to a crime. The newer interrogation approach is the information-gathering approach, also known as the investigative interview. It focuses on gathering accurate information in order to exclude or accuse a suspect in a criminal investigation. In comparison with coercive interrogation models, the information-gathering approach has a lower probability of false confessions since suspects are exposed to significantly lower levels of psychological pressure. Moreover, it is ethically more acceptable, has scientific grounds, enables the gathering of more accurate information, and has been found to be at least as effective as the coercive approach in criminal investigations. The investigative interview relies mainly on findings from social psychology. An analysis of coercive interrogation models reveals that they have no scientific basis and as such rely mainly on uncorroborated common-sense assumptions from authorities. In developed countries, coercive interrogation models are increasingly being replaced by the information-gathering approach, a trend connected with the enforcement of high human rights standards and a higher awareness of risks associated with coercive interrogation methods by the general public, academia, and professionals alike.
\end{abstract}

Keywords: interrogations, police, suspects, coercion, investigative interview

\section{Policijska zaslišanja skozi prizmo znanosti}

\author{
Igor Areh* \\ Fakulteta za varnostne vede, Univerza v Mariboru
}

Povzetek: Za pridobivanje informacij od človeških virov se uporablja več pristopov, ki se med seboj razlikujejo v teoretičnih temeljih, ciljih, izvedbi in etični sprejemljivosti. V članku sta kritično predstavljena in primerjana dva prevladujoča pristopa zasliševanj osumljencev, ki ju uporabljajo v policiji. Starejši in prevladujoč zasliševalski pristop je osredotočen na pridobivanje obremenilnih izjav ali priznanj s strani osumljencev, kar nevarno dviguje verjetnost pridobitve izsiljenega priznanja. Zaradi tega se ta pristop imenuje obtožilni ali prisilni, saj osumljence sili k priznanju. Novejši zasliševalski pristop, imenovan preiskovalni intervju, je osredotočen na pridobivanje točnih informacij, s katerimi policija išče dokaze za izločitev ali obdolžitev osumljenca. Verjetnost za obdolžitev in obsodbo nedolžne osebe je tako manjša, saj so osumljenci manj izpostavljeni psihičnim pritiskom. V primerjavi s prisilnim zasliševalskim pristopom je pristop zbiranja informacij etično bolj sprejemljiv, ima znanstvene temelje, omogoča pridobivanje bolj točnih informacij, pri preiskovanju kaznivih dejanj pa je vsaj toliko učinkovit kot prisilni pristop. V preiskovalno intervjuvanje so vgrajena predvsem spoznanja s področja socialne psihologije. Analiza prisilnih zasliševalskih modelov kaže, da so brez znanstvenoteoretičnih temeljev in so tako zasnovani predvsem na nepreverjenih zdravorazumskih domnevah strokovnih avtoritet. V vsesplošno bolj razvitih državah se prisilni model umika modelu zbiranja informacij, kar je povezano s praktičnim uveljavljanjem visokih standardov varovanja človekovih pravic in $\mathrm{z}$ ozaveščenostjo strokovne, akademske ter laične javnosti o tveganjih povezanih s prisilnimi zasliševalskimi metodami.

Ključne besede: zasliševanja, policija, osumljenci, prisila, preiskovalni intervju

\footnotetext{
*Naslov/Address: Igor Areh, Fakulteta za varnostne vede, Univerza v Mariboru, Kotnikova 8, 1000 Ljubljana, e-pošta: igor.areh@gmail.com 
Interrogation techniques used by the police, the military, and intelligence and security agencies have, over the past decades, received a great deal of attention from politicians, practitioners, researchers, and the general public (Kelly, Miller, \& Redlich, 2015). The increased level of interest is primarily the result of many notorious errors of the legal system and the police, due primarily to inappropriate training of interrogators and a low awareness of risks associated with psychological manipulation of suspects. Safeguards in the legal system designed to prevent the abuse of human rights and fundamental freedoms are not effective enough if their definition is too broad, if they are theoretically abstract, or if they are outlined by experts without the necessary background in psychology. Many research findings enable a critical evaluation of the application, effectiveness and disputability of interrogation techniques while also providing solutions that could be useful in gathering information from respondents who refuse to cooperate with investigators. This article presents a brief overview, a comparison and a synthesis of some findings important for recognizing the theoretical background and methodology of suspect interrogation.

Psychological manipulation techniques employed by police investigators in the interrogation of suspects have been well researched, especially in English-speaking countries (the USA, Great Britain, Australia, and Canada) and in Scandinavia. A clear lack of scientific psychological knowledge has often led to the expansion of pseudo-scientific practices employed by professionals without a background in psychology. Consequently, investigators tend to rely on common sense assumptions and employ investigative practices based on the suppositions of professional authorities, which are often theoretically unfounded and have not been scientifically proven. All this raises many questions and casts doubts on the ethical soundness and efficiency of police interrogations. To find answers, an overview of the development of police interrogation techniques is necessary, focusing on distinct paradigm shifts that have occurred over time. The beginning of the 1960s marked a decrease in coercive interrogation tactics employing physical abuse (e.g. shoving, tying up, slapping, beating with a rubber hose); threats; deprivation of sleep, water, food and other necessities; or causing the suspect to experience sensory discomfort (e.g. shining a bright light in one's face, pouring cold water over the suspect, exposure to heat or cold) (Leo, 2009). Due to public pressure in a society where human rights standards began to gain momentum following World War II (Flander, 2000), coercive tactics began to be replaced by the then more acceptable and deliberate psychologically manipulative techniques, including deception, trickery, lying and establishing control through submission and dependency on authority figures (Leo, 2009). This type of psychological suspect manipulation developed from common-sense assumptions and interrogators' previous experience. It seems that, despite the evolution of interrogation techniques, their main goal remained the same. Namely, investigators were primarily interested in eliciting confessions or incriminating statements, less so in establishing the truth (Kassin, 2008a).

In the early 1990s, United Kingdom was the birthplace of another shift in the use of interrogation techniques. An ethically more acceptable paradigm no longer aimed at extracting confessions and rooted in scientific research started to spread across western democracies. However, much like interrogative tactics employing physical abuse took decades to fade out, so the long-term process of replacing psychologically manipulative tactics with investigative interviewing has been ongoing for approximately 25 years. To this day, interrogative approaches continue to be dominated by techniques based on psychological manipulation of suspects, aimed at breaking down a suspect's resistance and inducing a confession (Walsh, Redlich, Oxburgh, \& Myklebust, 2016). Research evidence reveals a wide array of interrogative techniques being used to achieve the aforementioned aim. For example, 25 different techniques of psychological manipulation were found to exist in the USA (Leo, 1996), and 17 in the UK (Soukara, Bull, Vrij, Turner, \& Cherryman, 2009). One of the most extensive and influential studies has established the existence of as many as 71 interrogative techniques not only employed in police investigation, but also by intelligence and security agencies and the military (Kelly, Miller, Redlich, \& Kleinman, 2013). Research authors have grouped these techniques into six domains, as follows: (i) manipulation of the interrogative context (interrogation is conducted in a small, isolated room, deliberate choice of interrogation time and space, interrogator's outfit, etc.); (ii) relationship and rapport building (e.g. fostering respect, understanding, patience, emphasizing similarity with the suspect); (iii) emotion provocation (e.g. referring to the suspect's interests, conscience and religion, employing the prisoner's dilemma); (iv) confrontation and competition (e.g. emphasizing the investigator's expertise and authority, showing signs of impatience, use of deception and threats, submission of suspect); (v) collaboration (e.g. offering special rewards or bonuses, bargaining, appealing to the suspect's judgment); and (vi) presentation of evidence (e.g. presentation of real or contrived incriminating evidence, identifying contradictions in the suspect's statements) (Kelly et al., 2013).

Contrary to broad classifications, simpler classifi-cations are based on the dichotomization of interrogative techniques and are generally formulated as contrasts. For example, a frequently cited dichotomy is humane versus dominant interrogation tactics (Häkkänen, Ask, Kebbell, Alison, \& Granhag, 2009), but the most well established dichotomy is the accusatorial (coercive) versus the information-gathering method (Meissner, Redlich, Bhatt, \& Brandon, 2012). Because the latter dichotomy has become especially prominent, its interrogative categories should be presented in more detail.

\section{Coercive/accusatorial interrogation approach}

According to the proponents of this approach, interrogation is a guilt-presumptive process. Therefore, interrogations are aimed at extracting a confession from a suspect whom investigators already believe to be the perpetrator (Inbau, Reid, Buckley, \& Jayne, 2011). Accusatorial or coercive interrogation techniques (termed so because suspects are coerced to confess) are associated with establishing control over the suspect and using subtle psychologically manipulative tactics to elicit a confession (Kassin \& Gudjonsson, 
2004). Despite a rapid development of forensic science, the percentage of criminal offences where investigators lack material proof for the identification and conviction of offenders remains relatively high. In North America and the UK, $80 \%$ of investigated criminal offences committed approximately 20 years ago involved no material traces (Horvath \& Meesing, 1996). Today, this percentage is likely to be lower, but still high enough to maintain confession as an influential, desirable and very highly regarded proof of a suspect's guilt (Kassin, Kukucka, Lawson, \& DeCarlo, 2013). Accusatorial interrogation techniques are most widespread in North America and in some Asian countries (GoodmanDelahunty, Martschuk, \& Dhami, 2014); however, it must be emphasized that, in the USA, they have been steadily losing ground to an approach based on establishing rapport with the suspect (Redlich, Kelly, \& Miller, 2014).

Coercive or accusatorial interrogation methods generally consist of three phases. The first one is custody and isolation, aimed at heightening the suspect's anxiety. The second phase is confrontation, where the suspect is treated as an offender and confronted with incriminating evidence. Denial and resistance exhibited by the suspect following the accusation are systematically suppressed or undermined. In the third and final phase, interrogators show supposed sympathy in order to gain the suspect's trust. In doing so, they often manipulate suspects with techniques aimed at minimizing the seriousness of the offence, offering moral justification, and implying advantages or more lenient consequences in return for confessions (Kassin \& Gudjonsson, 2004).

A typical example of accusatorial or coercive interrogation methods is the Reid Technique (Inbau et al., 2011). It is the most influential and widely used approach in North America (Kassin, Appleby, \& Perillo, 2011), which has also successfully been exported to many other countries (John E. Reid and Associates, Inc., n.d.). The technique was developed by lawyers Fred Inbau and John Reid in the early 1940s (Gallini, 2010), who, surprisingly, gained a great deal of recognition with their ideas. Even though these legal professionals had no background in psychology, they are the most quoted experts in the field of psychological manipulation of suspects (Gallini, 2010). A lack of psychological and methodological knowledge is clearly apparent in their work; therefore, the scientific community regards them as pseudo-scientists who based their theory on practical experience instead of scientifically based findings (Gallini, 2010; Gudjonsson, 2003). The Reid Technique advocates the use of deception, lying and psychological pressure, but does not encourage physical threats and abuse. It is aimed at inducing admissions of guilt by relying on two processes, which are supposed to break down the suspects' denial and resistance, and heighten their need for confession (Inbau et al., 2011). Interrogation is conducted in nine consecutive steps and employs various manipulative tactics, including: minimization (minimizing the importance or seriousness of the offence); maximization (maximizing the consequences of the offence); rationalization (offering morally acceptable excuses for the offence); projecting blame onto the victim; using flattery or praise; breaking down the suspect's resistance and denial; alluding at the existence of incriminating evidence; appealing to the suspect's conscience or religion; employing the 'bad cop/good cop' routine, etc. (Inbau et al., 2011). The effectiveness of the Reid Technique, in other words the accuracy of detection of deception, remains unknown. Some authors report an $85 \%$ accuracy rate (Horvath, Jayne, \& Buckley, 1994), but this estimate is based on results of a study which fails to meet the most basic criteria for scientific research-it was conducted with insufficient experimental control and was biased toward a high accuracy of the Reid Technique (Kassin, 2008a). Independent research results do not corroborate the claims made by proponents of the Reid Technique. In fact, most researchers found that Reid's method cannot be used to separate truth tellers from liars (Kassin, 2008a). This finding is further supported by studies on the ability to distinguish between truth and lies. Namely, the results of meta-studies show that: (i) there are no behavioural cues indicative of lying, and that (ii) laypeople and trained professionals alike are fairly unsuccessful in lie detection, with the average performance being only slightly above chance (Bond \& DePaulo, 2006; Vrij, 2008). Thus, research findings do not support the claims of proponents of the Reid Technique and also emphasize that the technique is based on untested assumptions without a solid scientific or theoretical foundation.

Coercive interrogation techniques can be successful in eliciting true confessions of guilt. Their successfulness is the result of the interrogator's social influence on the suspect, as has been shown in many socio-psychological studies on compliance with authority (see Milgram, 2009; Zimbardo, 2007), conformity (see Asch, 1956; Bond \& Smith, 1996), and obedience (see Cialdini, 2008; Guéguen, Pascual, \& Dagot, 2002). However, it seems that the authors of coercive interrogation techniques are not familiar with the results of these studies - at least judging from their claims that innocent suspects would never be compelled to confess to a crime. Conversely, many research results have revealed that innocent suspects can falsely confess to a crime due to certain personality traits and situational circumstances (see Redlich \& Meissner, 2009). Today, it is well known that employing accusatorial interrogation techniques poses a serious threat of obtaining false confessions (Gudjonsson, 2003). The issue of false confessions has been relatively well researched, and several types have been identified, including: voluntary false confessions (an innocent suspect voluntarily admits to a crime), coerced-compliant false confessions (a suspect falsely confesses to avoid pressure and punishment or to receive a benefit or reward), and coerced-internalized false confessions (an innocent suspect confesses under pressure and comes to believe that they indeed committed the crime) (Kassin \& Wrightsman, 1985). One of the main reasons for extracting false confessions is a strong bias on the part of the investigators who are mainly convinced of the suspect's guilt (Areh, Walsh, \& Bull, 2015; Meissner \& Kassin, 2002). This conviction leads to what is known as the 'confirmation bias', which means that investigators unwillingly consider only the evidence consistent with their expectations and ignore, exclude, or reinterpret the disconfirming evidence (Nickerson, 1998). Conviction of the suspect's guilt therefore increases the probability that an interrogation will be biased against the suspect, but this is not the only consequence of investigator bias. Because of their conviction of the suspect's guilt, investigators tend to use questionable interrogation tactics more often, conduct more aggressive interrogations (Kassin \& Gudjonsson, 2004) and are less thorough in their 
preparation for the interrogation (Walsh \& Milne, 2007). Moreover, conviction of a suspect's guilt means that there is no place for a presumption of innocence in the pre-trial process when the police investigate a crime. Instead, a presumption of innocence is only possible later, when the court decides on a suspect's guilt during the criminal procedure, which is alarming. It means that investigators can previously extract false confessions or obtain incriminating statements and then provide a false interpretation of evidence to the court through a prosecutor, having tragic consequences for the accused.

To sum up: the validity of coercive or accusatorial interrogation techniques is not scientifically tested and is thus based only on the assumptions and authority of their authors (Vrij, 2008). Therefore, we cannot speak of any scientific or theoretical foundation of coercive interrogation methods. Unfortunately, investigators and other practitioners are often not aware of this finding and fail to see it as a problem. Proponents of coercive interrogation tactics frequently claim that their technique can be considered as a scientific process or method, which is not the case. Police officers are not trained to employ scientific methods-generally used to mean formulation and testing of hypotheses in order to confirm or dispute theories-and therefore do not use them in practice. Testing of hypotheses during interrogation only resembles scientific research, so it cannot be referred to as the scientific method. The scientifically controversial nature of interrogations is mainly reflected by: (i) untested and subjective techniques used to detect lies; (ii) the presumption of guilt, leading to 'confirmation bias'; and (iii) non-standardized interrogation procedures which can be altered randomly and without regulation (Redlich \& Meissner, 2009). Proponents of accusatorial interrogation approaches are not concerned about the findings that show many of these techniques to be unethical (Vrij, 2008) and ineffective when it comes to gathering true information (Holmberg \& Christianson, 2002). They mostly disregard scientific evidence because they fail to see the difference between common sense judgement and scientific research (Vrij, 2008). In general, accusatorial or coercive interrogation is questionable for both its pseudo-scientific foundation and the violation of ethical principles and human rights. Perhaps it should not come as a surprise that this interrogation approach is most widespread in countries prone to impose severe punitive or reprisal measures on perpetrators. In these societies, the violation of suspects' human rights is regarded as less obtrusive (Flander \& Meško, 2013). This is probably also the reason why, in countries where the tendency to inflict punishment on perpetrators is not as highly expressed, ethically more acceptable methods of gathering information have been gaining in importance.

\section{Information-gathering approach}

This approach is employed to obtain information and is focused on collecting facts connected with a crime and not on eliciting confessions (Bull \& Soukara, 2010), which significantly reduces the possibility of employing psychological pressure and deception (Dixon, 2010). Importantly, the term 'interrogation' is no longer used in connection with this approach and has been replaced with the term 'investigative interview', highlighting the importance of establishing rapport with the suspect. The first interviewing method with information gathering was termed PEACE and appeared in the UK in the early 1990s, but its implementation was not spontaneous. After a series of high profile cases involving wrongful convictions of innocent persons, a surge of research on investigative practices ensued, largely financed by the state through public projects (Dixon, 2010). This paved the way for laying solid scientific and theoretical foundations of investigative practices where psychologically manipulative techniques became unacceptable (Clarke \& Milne, 2001). Because this approach to investigative interviewing is likely to replace the traditional interrogative practices in many countries, it should be explained in further detail. The mnemonic acronym PEACE stands for five separate parts of the investigative interview (Gudjonsson, 2003; Shepherd, 2007):

1. Preparation and Planning (P). Investigators prepare for the interview by defining its aim and making a detailed plan. Interview implementation depends on the type of interviewee (suspect, victim or witness), the type of criminal offence committed, and its context.

2. Engage and Explain (E). The interviewee is told the reasons for conducting the interview, introduced to the persons present and informed of their Miranda rights (the rights to silence and to not make self-incriminating statements). During this stage, rapport is established, incriminating evidence is presented and the interviewee is engaged in conversation.

3. Account (A). This stage constitutes the core of the interview in which information is obtained from the interviewee. Their account should be uninterrupted and followed primarily by open-ended questions from the interviewer (e.g. Tell us what happened). At the end of the phase, interviewees are presented with any contradictions or inconsistencies and asked to clarify their account.

4. Closure (C). The interviewer summarises the account, making sure the interviewee agrees with it and enquiring whether they wish to add or change anything.

5. Evaluate (E). Interviewers evaluate the information obtained, analyse the effectiveness of the interview and reflect on the way it was conducted (supervision).

The investigative interview model promotes a planned, deliberate and ethical method of interviewing, urging investigators to remain impartial and thus obtain more accurate information (Oxburgh \& Dando, 2011). It should be emphasized that, within the PEACE framework, all interviews with suspects must be recorded. Thus, suspects are protected from any misrepresentation from the police (Walsh \& Bull, 2013), while investigators are protected from possible false allegations of misconduct and enjoy higher credibility of their work (Sullivan, Vail, \& Anderson, 2008).

Contrary to coercive interrogation techniques, investigative interviewing is based on empirical research results and not investigators' subjective experience (Dixon, 2010). An analysis has revealed that proponents of coercive 
interrogation lack basic psychological knowledge, which is certainly not the case with the information-gathering approach. In planning an investigative interview, the findings on suggestibility, compliance, obedience and social influence are considered. As a result, research on the effectiveness of the information-gathering approach has confirmed it as a justified and effective substitute for the coercive interrogation method. In other words, the latest evaluation studies show that the accuracy of gathered information is greater with investigative interviewing and that the possibility of eliciting false confessions is lower compared to coercive interrogation methods (Evans et al., 2013; Kassin, 2008a). The reason behind the greater accuracy of gathered information is that suspects are more likely to cooperate with police officers if they are treated respectfully, politely, and with understanding (Vandrehallen, Vervaeke, \& Holmberg, 2011).

These findings counter the myth propagated by coercive interrogation technique proponents, namely that most perpetrators are unwilling to confess even their involvement in a criminal offence, much less their guilt. However, research evidence shows that a minority of suspects are determined to deny their involvement in an offence prior to being interrogated (Deslauriers-Varin, Lussier, \& St-Yves, 2011). Also interesting are research findings showing that only $50 \%$ of sex offenders made plans to either confess or deny their guilt before the first police interview. Of these, $20 \%$ planned to deny and $30 \%$ planned to confess, while the other half did not make their minds up about confessing or denying before the interview (Kebbell, Hurren, \& Mazerolle, 2006). This could imply that most perpetrators are irresolute about confessing before the first police interview and make their decision later, depending on the interrogation method (Kebbell et al., 2006).

If the accusatorial approach is employed, there is a greater chance that true perpetrators will resist and deny their guilt (Vandrehallen et al., 2011), a phenomenon explained by Gudjonsson (2003) as the reactance theory. That is, when pressured to adopt certain views or beliefs, a person will adopt or reinforce the exact opposite views and express resistance if pressured further (Miron \& Brehm, 2006). Furthermore, reactance can trigger opposition to demands or expectations (Buller, Borland, \& Burgoon, 1998), resulting in a negative attitude towards the authority figure (Miller, Lane, Deatrick, Young, \& Potts, 2007). A more detailed analysis has revealed that reactance significantly increases with authoritative and dogmatic communication (Miller et al., 2007) characterized by the use of the imperative case, accusations, rash conclusions without considering the other person's opinion (Quick \& Stephenson, 2008), and the use of implicit threats (Bushman, 1998). Conversely, unbiased communication-for example, avoiding derision and commands, and offering a choice between acceptable options (Quick \& Stephenson, 2008) - lowers the chance of reactance to appear (Bushman, 1998).

It seems that behaving in a respectful, credible manner without restricting the freedom to views, opinions or alternatives makes it easier to influence somebody (Silvia, 2005). These findings are extremely relevant for efficient investigative interviewing as they could solve an issue frequently arising in police interrogation: suspects' resistance or uncooperative behaviour towards the police, which, as was described earlier, is often linked to investigators' authoritative approach. This approach is, in turn, typically associated with coercive interrogation methods.

If cooperation between the suspect and investigator is to be achieved, good rapport should therefore be established between them. Unsurprisingly, rapport has been emphasized as the most significant and relevant element of investigative interviewing (Vanderhallen \& Vervaeke, 2014). Good rapport (i) yields more detailed accounts (Walsh \& Bull, 2012); (ii) encourages extraction of true confessions (GoodmanDelahunty et al., 2014); (iii) reduces resistance of suspects compared to coercive interrogation techniques (Alison et al., 2014); and (iv) increases cooperation between a suspect and the police (Holmberg \& Madsen, 2014; Vandrehallen et al., 2011). The rapport model most frequently mentioned in relation with police interrogation was proposed by TickleDegnen and Rosenthal (1990), and is based on three mainly behavioural factors: (i) mutual attention (level of interaction between partners); (ii) positivity (positive feelings of mutual friendliness and respect); and (iii) coordination (expressed by behavioural synchrony between partners). In investigative interviewing, the use of behavioural cues fostering rapport is extremely important. These cues range from contact behaviour (e.g. a forward lean, eye contact) and active listening to verbal and nonverbal mimicry (Brandon, 2014). In contrast to coercive interrogation models, these behavioural cues have been empirically tested and are not based on assumptions.

As previously mentioned, information-gathering approaches decrease the risk of false confessions (Meissner et al., 2012) because police officers do not exert psychological pressure to lead the suspect into believing it is in their best interest to confess (Gudjonsson, 2003). Although this is an important advantage of investigative interviewing, this approach is not as flaw-free as it might seem. In fact, research has shown that interviewers rarely follow all the recommendations for conducting an investigative interview (Clarke, Milne, \& Bull, 2011), and even well experienced, trained investigators must constantly strive to apply these recommendations (Soukara et al., 2009). Thus, the information-gathering approach seems perfect in theory, but is actually less than perfect in practice. Nevertheless, research has revealed that investigative interviewing is at least as effective in investigating criminal offences as the coercive interrogation model (e.g. Evans et al., 2013).

The information-gathering approach is becoming increasingly established and has already replaced the conventional accusatorial techniques in many countries. In addition to the UK, it has become generally accepted in Australia and New Zealand (Ord, Shaw, \& Green, 2011), and has also raised much attention in continental Europe (Williamson, Milne, \& Savage, 2009). For example, new models of investigative interviewing have developed in the Netherlands and in Scandinavian countries (Fahsing \& Rachlew, 2012). It seems that more developed European countries are steering away from coercive interrogation tactics. 


\section{Discussion}

The differences between the coercive (accusatorial) interrogation approach and the information-gathering approach are pronounced and become relevant when selecting an interrogation technique. If the goal of an interrogation is to establish the truth, then the information-gathering approach is the more justified, suitable choice. Not only does this approach yield more information, but also the obtained information is more accurate and the risk of false confessions is lower. Moreover, the investigative interview model is based on scientific findings, it reduces the possibility of violating the interviewee's human rights, and protects the integrity of police officers' work more. Because all investigative interviews with suspects must be recorded, a reliable and accurate insight into the communication and relationship between interviewer and interviewee is available at any time.

In discussing the differences between the coercive interrogation approach and the information-gathering approach, the interrogation model used in Slovenia deserves some attention. It seems that it could not be characterized as completely coercive, yet certain techniques employed are typical of the coercive approach (Areh et al., 2015). When Slovenia was part of the Socialist Federal Republic of Yugoslavia, coercive interrogation techniques were well known as some were recommended for interrogation of suspects (Areh, Zgaga, \& Flander, 2016). They were later included in the first Slovenian interrogation manual dating from 2003 (Štirn \& Podvršič, 2003), an internal document drafted by the Ministry of the Interior which never went to print. The manual is still available to Slovenian police officers, so it is not surprising that, with police training methods often being reflected in investigative practice (King \& Snook, 2009; Leo, 1996), coercive techniques can be found in existing investigative practice.

A suspect interview in Slovenia normally lasts 90 minutes and is not recorded (Areh et al., 2015) - the latter fact being especially worrying as there is no reliable insight into what exactly happens during an interrogation. Besides, interviewers cannot learn from the feedback provided (Sullivan, 2004). Lack of recording offers suspects the option of manipulating the justice system by, for example, lying about the interrogation, and allows investigators to employ illegal psychologically manipulative tactics on suspects. Although attorneys are generally present during an interrogation, this fact alone cannot guarantee a high level of protection of suspects' rights. Attorneys are often not sufficiently familiar with specific techniques of psychological manipulation, so they do not always intervene during an interrogation when necessary. Moreover, they are not present during the preliminary interview, making it easier to (implicitly) use a wide array of manipulative techniques at this stage. Since police officers in Slovenia obtain most information in preliminary interviews (interrogations being extremely rare), the absence of interview recordings casts doubts on the ostensibly high standards of suspects' human rights protection. Countries where coercive interrogation methods are employed are characterized by a reluctance of police officers towards recording interrogations. In part, the reluctance derives from their fear that others would gain an insight into and could monitor the efficiency of their work (Sullivan, 2004). However, research results have shown that, once recordings become a common part of interrogation practice, investigators approve of them. Actually, recording has a host of collateral benefits reflected by greater reliability and efficiency of police work (Sullivan et al., 2008). Analysing the recordings helps investigators increase the efficiency of their work and learn from mistakes, while recordings also protect them from manipulative attempts of suspects. Proponents of coercive interrogation techniques often state that recording could disturb an interrogation. Therefore, they recommend that a recording be implemented covertly if it must be done (Inbau et al., 2011). Again, there are no scientific findings corroborating the claim that making a recording presents a disturbance, which means that this is just another common sense presumption.

The most widely used interrogation techniques in Slovenia are, for the most part, those recommended in coercive interrogation manuals, such as: faking empathy, appealing to the suspect's religion and conscience, offering moral justifications for the offence, referring to the existence of incriminating evidence, employing the good cop/bad cop routine, minimizing the seriousness of the offence, appealing to the suspect's self-interest, and using a polygraph as a diagnostic tool for lie detection (Areh et al., 2015). Polygraph examinations are generally classified as coercive interrogation methods (Kassin, 2008b), with a polygraph test generating more anxiety compared to other interrogation techniques and therefore having an intimidating effect both on innocent and guilty suspects (British Psychological Society, 2004). Using the polygraph increases the rate of false confessions (Kassin, 2008b), in addition to being a scientifically and ethically questionable method which, as such, cannot have any evidential value in criminal investigation procedures (British Psychological Society, 2004). It should be stressed that, in Slovenia, the polygraph is used only as an investigative tool, assisting investigators in narrowing down the suspect list and not proving a suspect's guilt (Areh, 2011). In any case, a polygraph should never be used for psychological manipulation of suspects, as suggested by the proponents of coercive interrogation models. One of their suggestions is to inform a suspect that they failed the polygraph test even if this is not the case, and observe their reaction (see Lykken, 1998). The purpose of this tactic is to elicit a confession; however, this is an example of coercive interrogation involving deceit and psychological manipulation. Due to its controversial nature, a polygraph is generally not used by investigators relying on information-gathering methods. Clearly, intimidation would make it hard to establish good rapport with the suspect.

Moreover, coercive interrogation models are plagued by yet another crucial issue: investigators' belief that they are almost always interrogating guilty suspects (Kassin et al., 2007; Walsh \& Milne, 2007). This has also been confirmed among Slovenian criminal investigators, who believe the suspect is the true perpetrator in $90 \%$ of interrogations (Areh et al., 2015). In comparison, British investigators were convinced of the suspect's guilt in $73 \%$ of interrogations 20 years ago (Stephenson \& Moston, 1993), but this share has 
decreased to two thirds in a more recent study (Walsh \& Milne, 2007), probably as a result of the transition from coercive interrogation techniques to information-gathering techniques. Guilt-presumptive interrogation poses a greater risk for a biased investigation, leading investigators to conduct more aggressive interrogations that could elicit a false confession, result in a wrongful conviction, or leave investigators puzzled due to misleading or induced information obtained.

Over the last decade, scientific evidence on police interrogations has grown and now offers a reliable insight into different methods of suspect interrogation and the risks associated with each one (Redlich \& Meissner, 2009). Despite being recognized as controversial, accusatorial or coercive interrogation approaches continue to be widely used, especially in the USA, and then exported to other countries. Importantly, changes in this field have also taken place in the USA. In 2009, President Obama's administration started financing a research program to establish which interviewing techniques are most effective and scientifically supported (Brandon, 2014). This might mean that the relevance of investigative interviewing or the information-gathering approach will soon be established.

The current domination of coercive interrogation techniques is related to inadequate training of the police and the judiciary, and their unfamiliarity with psychological findings revealing the controversial nature of coercive approaches. And yet, if past scientific research has mainly exposed controversies associated with police interrogations, findings of the last decade have focused primarily on developing and testing techniques which yield more accurate information and more reliable evidence (Meissner, Hartwig, \& Russano, 2010). In cooperation with investigators, researchers can suggest much less controversial yet equally effective methods of gathering information and establishing the truth. Over the past twenty years, an alternative interrogation approach exemplified by the British PEACE model has been gaining momentum. The main advantage of investigative interviewing is its solid foundation on psychological findings and theories.

When it comes to police interrogations, the two most prominent and influential theories are Gudjonsson's suggestibility theory (see Gudjonsson, 2003) and the reactance theory (see Miller et al., 2007). In his theory, Gudjonsson discusses interrogative suggestibility and defines it as susceptibility to investigator's suggestions, which can be an important psychological vulnerability of interviewees' during police interrogation (Gudjonsson, 2003). According to research results, stressful life experience may correlate with greater interrogative suggestibility, which means that suspects are less able to defend or assert themselves (see Gudjonsson, Sigurdsson, \& Sigfusdottir, 2009). With this in mind, it is not difficult to understand why coercive interrogation techniques represent a serious risk of eliciting erroneous information and false confessions.

The reactance theory and the research findings supporting it offer useful advice for conducting an effective and ethical investigative interview. Because coercive interrogation techniques may result in increased resistance of suspects, obtaining relevant information and confessions becomes less possible. We speak of the boomerang effect, where accusatorial and disparaging interrogation methods elicit a similarly negative attitude from suspects (Gudjonsson, 2003) who refuse to cooperate with investigators. Establishing good rapport therefore seems like an effective solution in breaking down suspects' resistance and increasing their cooperation with investigators. In theory, this is a significant advantage of investigative interviews over coercive interrogation, but, without a recording, the door for psychological manipulation still remains open. Even if investigators are advised against using existing coercive interrogation techniques, a host of persuasive techniques remains available to achieve suspects' compliance and obedience (see Cialdini, 2008). Discussing all methods and techniques involving social influence would far exceed the scope of this article, so let us look at just some examples that pose a risk in interrogations.

One of the more widely used coercive techniques is the good cop/bad cop routine, which involves at least two police officers. One of them takes a hostile approach to the suspect, and the other one acts sympathetically. The threatening approach of the 'bad cop' increases fear of the legal consequences, making the sympathetic officer seem like a kind and understanding person protecting the suspect due to the perceptual contrast principle (see White \& Kamisar, 1981). The resulting reciprocity effect (see Leakey \& Lewin, 1979; Wedekind \& Milinski, 2000) makes the suspect feel obliged to return the favour to the 'good cop', revealing anticipated information or even confessing to a crime in order to express gratitude and fulfil the commitment. If police officers wear a uniform, a suit or some other outfit symbolizing authority, this alone can suffice to produce a tendency towards obedience and submissiveness, which is difficult to resist (Bushman, 1988). The reciprocity effect, the perceptual contrast principle and the effect of a uniform can also be present in investigative interviewing. Furthermore, precisely because interviewers aim at establishing rapport and trust in information-gathering approaches, they must be careful not to become overly friendly and similar to the interviewee. Excessive emphasis on the similarities between the interviewer and interviewee, and an effort to achieve likeability, may lead to compliance (Cialdini, 2008), compelling the interviewee to provide misleading information. The same goes for flattery, which, if used too obviously, can also produce increased resistance and denial (Cialdini, 2008). Recording the interviews is thus essential to ensure reliability of the obtained information and ethical soundness of the investigators' work.

Finally, two significant drawbacks of using coercive approaches should be mentioned. Coercive interrogation is connected with feelings of humiliation, disappointment, offense and deceit, which can lead to a break in cooperation with the police and the judiciary and even arouse a desire for revenge. If suspects confess due to their being confronted with sound incriminating evidence, negative emotions are less likely to surface (Gudjonsson, 2003). Moreover, coercive interrogation tactics can result in 'the blue curtain', or police corruption and reluctance to report other officers' misconduct and crimes (Leo, 1996). When cases of police misconduct leak out, the public is appalled and the reputation of the police and the judiciary suffers.

Some experts believe that the integrity of the judicial system and the police can also be gauged by how much effort is invested into reducing the risk of justice miscarriages (Huff $\&$ Kilias, 2008). Here, the police with their investigative work bear the brunt of the responsibility (Martin, 2002). However, 
scientists must also contribute to the ethical administration of justice by advocating legal changes and helping the police professionalize their work (Milne, Poyser, Williamson, $\&$ Savage, 2010). Yet both the judiciary and the police are reluctant to embrace scientific evidence, and often go as far as to oppose the application of scientific findings and research methods. This opposition could originate from a difference in mentalities typical of psychologists and legal professionals. Ogloff and Finkelman (1999) identify a number of such differences, including: (i) law is authoritative, psychology is empirical; (ii) law is conservative, psychology is creative; (iii) law is prescriptive, psychology is descriptive; (iv) law is definitive, psychology is probabilistic; (v) law is operational, psychology is scientific; and (vi) law relies on adversarial process, psychology relies on experimentation. Clearly, law and psychology are two different worlds; and yet, if their goal is to establish the truth, the judiciary and the police will have to work hand in hand with science.

The differences between law and psychology are not, however, the only reason for the reluctance to accept scientific evidence. Many pseudo-scientific ideas offering apparent shortcuts to solving problems have also found their way into the police and legal practice. Unlike scientific methods, they promise certainty combined with fast, simple answers, and therefore seem more enticing (Daempfle, 2014). The desire to make a profit also contributes to these methods spreading faster and enjoying more success compared to scientific methods. What is more, the reluctance to scientific methods can be due to the popularity of deeply rooted common sense assumptions. Consequently, the use of coercive interrogation techniques does not seem as questionable to the general public, the police and the judiciary as it does to the scientific community. For example, most people believe that an innocent suspect would never confess to a crime unless they were tortured or mentally ill (Kassin \& Gudjonsson, 2004). Such a belief seems reasonable, since most people have never been subjected to police interrogation. Erroneous beliefs are more tenacious and dangerous if investigators receive insufficient or infrequent trainings. Thus, they are left to rely on personal common sense assumptions about the efficiency of interrogation methods, mainly generated by selective memory recall of previous work experiences (Massip, Herrero, Garrido, \& Barba, 2011). As a result, coercive interrogation techniques are employed in practice and hard to eliminate. In the UK, research evidence has shown that, despite regular and systematic trainings of police officers, a tendency to go back to the traditional investigative routine keeps emerging and must be supressed (Clarke et al., 2011; Soukara et al., 2009).

Slovenian legislation prohibits the use of deception, lies and deceit, which could be taken into account in planning a strategic transition to a modern interrogation approach based on gathering information instead of eliciting confessions. Perhaps the first and most necessary step to implementing improvements is making the recording of interrogations obligatory. This would also ensure the supervision and professional development of criminal officers. It is in society's best interest for police officers to conduct their work as professionally as possible, so they can put true perpetrators behind bars and help innocent suspects go free.

\section{References}

Alison, L. J., Alison, E., Noone, G., Elntib, S., Waring, S., \& Christiansen, P. (2014). Whatever you say, say nothing: Individual differences in counter interrogation tactics amongst a field sample of right wing, AQ inspired and paramilitary terrorists. Personality and Individual Differences, 68, 170-175.

Areh, I. (2011). Forenzična psihologija: Predstavitev, pričanje in ugotavljanje laži [Forensic psychology: Introduction, eyewitness testimony, and detecting lies]. Ljubljana: Fakulteta za varnostne vede.

Areh, I., Walsh, D., \& Bull, R. (2015). Police interrogation practice in Slovenia. Psychology, Crime and Law. Advance online publication. doi: 10.1080/1068316x.2015.1114113

Areh, I., Zgaga, S., \& Flander, B. (2016). Police interrogation in Slovenia: Selected legal and psychological aspects. In D. Walsh, G. Oxburgh, A. Redlich, \& T. Myklebust (Eds.), International developments and practices in investigative interviewing and interrogation: Vol. 2. Suspects (pp. 204-214). London, United Kingdom: Routledge.

Asch, S. E. (1956). Studies of independence and conformity: A minority of one against a unanimous majority. Psychological Monographs: General and Applied, 70(9), $1-70$.

Bond, C. F. \& DePaulo, B. M. (2006). Accuracy of deception judgments. Personality and Social Psychology Bulletin, 10, 214-234.

Bond, R. \& Smith, P. B. (1996). Culture and conformity: A meta-analysis of studies using Asch's (1952b, 1956) line judgment task. Psychological Bulletin, 119, 111-137.

Brandon, S. E. (2014). Towards a science of interrogation. Applied Cognitive Psychology, 28, 945-946.

British Psychological Society. (2004). A review of the current scientific status and fields of application of polygraphic deception detection: Final report from the BPS Working Party. Leicester, United Kingdom: Author.

Bull, R. \& Soukara, S. (2010). Four studies of what really happens in police interviews. In G. D. Lassiter \& C. A. Meissner (Eds.), Police interrogations and false confessions: Current research, practice, and policy recommendations (pp. 81-95). Washington, DC, USA: American Psychological Association.

Buller, D. B., Borland, R., \& Burgoon, M. (1998). Impact of behavioural intention on effectiveness of message features: Evidence from the family sun safety project. Human Communication Research, 24, 433-453.

Bushman, B. J. (1988). The effects of apparel on compliance: A field experiment with a female authority figure. Personality and Social Psychology Bulletin, 14, 459-467.

Bushman, B. J. (1998). Effects of warning and information labels on consumption of full-fat, reduced-fat, and no-fat products. Journal of Applied Psychology, 83, 97-101.

Cialdini, R. B. (2008). Influence: Science and practice. Boston, MA, USA: Allyn and Bacon.

Clarke, C. \& Milne, R. (2001). National evaluation of the PEACE investigative interviewing course: Police Research Award Scheme. London, United Kingdom: Home Office. 
Clarke, C., Milne, R., \& Bull, R. (2011). Interviewing suspects of crime: The impact of PEACE training, supervision, and the presence of a legal advisor. Journal of Investigative Psychology and Offender Profiling, 8, 149-162.

Daempfle, P. A. (2014). Good science, bad science, pseudoscience, and just plain bunk: How to tell the difference. Plymouth, United Kingdom: Rowman \& Littlefield Publishers.

Deslauriers-Varin, N., Lussier, P., \& St-Yves, M. (2011). Confessing their crime: Factors influencing the offender's decision to confess to the police. Justice Quarterly, 28, 113-145.

Dixon, D. (2010). Questioning suspects: A comparative perspective. Journal of Contemporary Criminal Justice, 26, 426-440.

Evans, J. R., Meissner, C. A., Ross, A. B., Houston, K. A., Russano, M. B., \& Horgan, A. J. (2013). Obtaining guilty knowledge in human intelligence interrogations: Comparing accusatorial and information-gathering approaches with a novel experimental paradigm. Journal of Applied Research in Memory \& Cognition, 2, 83-88.

Fahsing, A. \& Rachlew, A. (2012). Investigative interviewing in the Nordic region. In T. Williamson, B. Milne, \& S. Savage (Eds.), International developments in investigative interviewing (pp. 39-65). New York, NY, USA: Routledge.

Flander, B. (2000). Mednarodni mehanizmi in standardi varstva človekovih pravic: posameznik v mednarodnih sistemih varstva človekovih pravic [International mechanisms and standards of human rights protection: An individual in international systems of human rights protection]. In B. Lobnikar \& J. Žurej (Eds.), Raziskovalno delo podiplomskih študentov Slovenije: Družboslovje in humanistika [Reseach work of Slovenian postgraduate students: Social sciences and humanities] (pp. 1-15). Ljubljana, Slovenia: Društvo mladih raziskovalcev Slovenije.

Flander, B. \& Meško, G. (2013). Punitivnost in kaznovalni populizem v Sloveniji [Punitivity and penal populism in Slovenia]. Revija za kriminalistiko in kriminologijo, 64, 330-344.

Gallini, B. R. (2010). Police 'Science' in the interrogation room: Seventy years of pseudo-psychological interrogation methods to obtain inadmissible confessions. Hastings Law Journal, 61, 529-580.

Goodman-Delahunty, J., Martschuk, N., \& Dhami, M. K. (2014). Interviewing high value detainees: Securing cooperation and disclosures. Applied Cognitive Psychology, 28, 883-897.

Gudjonsson, G. H. (2003). The psychology of interrogations and confessions: A handbook (2nd ed.). Chichester, United Kingdom: John Wiley \& Sons.

Gudjonsson, G. H., Sigurdsson, J. F., \& Sigfusdottir, I. D. (2009). Interrogations and false confessions among adolescents in seven countries in Europe: What background and psychological factors best discriminate between false confessors and non-false confessors? Psychology, Crime and Law, 15, 711-728.

Guéguen, N., Pascual, A., \& Dagot, L. (2002). Low-ball and compliance to a request: An application in a field setting. Psychological Reports, 91, 81-84.
Häkkänen, H., Ask, K., Kebbell, M., Alison, L., \& Granhag, P. A. (2009). Police officers' views of effective interview tactics with suspects: The effects of weight of case evidence and discomfort with ambiguity. Applied Cognitive Psychology, 23, 468-481.

Holmberg, U. \& Christianson, S. Å. (2002). Murderers' and sexual offenders' experiences of police interviews and their inclination to admit or deny crimes. Behavioral Sciences \& the Law, 20, 31-45.

Holmberg, U. \& Madsen, K. (2014). Rapport operationalized as a humanitarian interview in investigative interview settings. Psychiatry, Psychology and Law, 21, 591-610.

Horvath, F., Jayne, B., \& Buckley, J. (1994). Differentiation of truthful and deceptive criminal suspects in behavior analysis interviews. Journal of Forensic Sciences, 39, 793-807.

Horvath, F. \& Meesig, R. (1996). The criminal investigation process and the role of forensic evidence: A review of empirical findings. Journal of Forensic Sciences, 41, 963-969.

Huff, R. C. \& Killias, M. (2008). Wrongful conviction: Conclusions from an international overview. In R. C. Huff \& M. Killias (Eds.), Wrongful conviction: International perspectives on miscarriages of justice (pp. 287-300). Philadelphia, PA, USA: Temple University Press.

Inbau, F. E., Reid, J. E., Buckley, J. P., \& Jayne, B. C. (2011). Criminal interrogation and confessions (5th ed.). Gaithersberg, MA, USA: Jones \& Bartlett Publishers.

John E. Reid and Associates, Inc. (n.d.). Company information. Retrieved from http://www.reid.com/r_about.html

Kassin, S. M. (2008a). Confession evidence commonsense myths and misconceptions. Criminal Justice and Behavior, 35, 1309-1322.

Kassin, S. M. (2008b). The psychology of confessions. Annual Review of Law and Social Science, 4, 193-217.

Kassin, S. M., Appleby, S. C., \& Perillo, J. T. (2011). Interviewing suspects: Practice, science, and future directions. Legal and Criminological Psychology, 15, $39-55$.

Kassin, S. M. \& Gudjonsson, G. H. (2004). The psychology of confessions: A review of the literature and issues. Psychological Science in the Public Interest, 5, 33-67.

Kassin, S. M., Kukucka, J., Lawson, V. Z., \& DeCarlo, J. (2013). Does video recording alter the behavior of police during interrogation? A mock crime-and-investigation study. Law and Human Behavior, 38, 73-83.

Kassin, S. M., Leo, R. A., Meissner, C. A., Richman, K. D., Colwell, L. H., Leach, A. M., \& Fon, D. L. (2007). Police interviewing and interrogation: A self-report survey of police practices and beliefs. Law and Human Behavior, 31, 381-400.

Kassin, S. M. \& Wrightsman, L. S. (1985). Confession evidence. In S. M. Kassin \& L. S. Wrightsman (Eds.), The psychology of evidence and trial procedure (pp. 67-94). Beverly Hills, CA, USA: Sage. Retrieved from http://www.williams.edu/Psychology/Faculty/Kassin/ files/kassin_wrightsman_1985.pdf

Kebbell, M., Hurren, E., \& Mazerolle, P. (2006). An investigation into the effective and ethical interviewing of suspected sex offenders: Final report to the Australian Criminology Research Council. 
Kelly, C. E., Miller, J. C., \& Redlich, A. D. (2015). The dynamic nature of interrogation. Law and Human Behavior. Advance online publication.

Kelly, C. E., Miller, J. C., Redlich, A. D., \& Kleinman, S. M. (2013). A taxonomy of interrogation methods. Psychology, Public Policy, and Law, 19, 165-178.

King, L. \& Snook, B. (2009). Peering inside the Canadian interrogation room: An examination of the Reid model of interrogation, influence tactics, and coercive strategies. Criminal Justice and Behavior, 36, 674-694.

Leakey, R. \& Lewin, R. (1979). People of the Lake: Mankind $\&$ its beginnings. Dresden, TN, USA: Avon Books.

Leo, R. A. (1996). Inside the interrogation room. Journal of Criminal Law \& Criminology, 86, 266-303.

Leo, R. A. (2009). Police interrogation and American justice. Cambridge, MA, USA: Harvard University Press.

Lykken, D. T. (1998). A tremor in the blood: Uses and abuses of the lie detector. Reading, MA, USA: Perseus Books.

Martin, D. L. (2002). The police role in wrongful convictions: An international comparative study. In J. A. Humphrey \& S. D. Westervelt (Eds.), Wrongly convicted: Perspectives on failed justice (pp. 77-95). Brunswick, OH, USA: Rutgers University Press.

Masip, J., Herrero, C., Garrido, E., \& Barba, A. (2011). Is the behaviour analysis interview just common sense? Applied Cognitive Psychology, 25, 593-604.

Meissner, C. A., Hartwig, M., \& Russano, M. B. (2010). The need for a positive psychological approach and collaborative effort for improving practice in the interrogation room. Law \& Human Behavior, 34, 43-45.

Meissner, C. A. \& Kassin, S. M. (2002). "He's guilty!": Investigator bias in judgments of truth and deception. Law and Human Behavior, 26, 469-480.

Meissner, C. A., Redlich, A. D., Bhatt, S., \& Brandon, S. (2012). Interview and interrogation methods and their effects on investigative outcomes. Campbell Systematic Reviews, 13.

Milgram, S. (2009). Obedience to authority: An experimental view. New York, NY, USA: Harper Perennial Modern Classics.

Miller, C. H., Lane, L. T., Deatrick, L. M., Young, A. M., \& Potts, K. A. (2007). Psychological reactance and promotional health messages: The effects of controlling language, lexical concreteness, and the restoration of freedom. Human Communication Research, 33, 219-240.

Milne, R., Poyser, S., Williamson, T., \& Savage, S. (2010). Miscarriages of justice: What can we learn? In J. Adler \& J. Gray (Eds.), Forensic Psychology: Concepts, Debates and Practice (pp. 17-36). New York, NY, USA: Willan.

Miron, A. M. \& Brehm, J. W. (2006). Reaktanz theorie - 40 Jahre spater [Reactance theory - 40 years later]. Zeitschrift für Sozialpsychologie, 37(1), 9-18.

Nickerson, R. S. (1998). Confirmation bias: A ubiquitous phenomenon in many guises. Review of General Psychology, 2, 175-220.

Ogloff, J. R. P. \& Finkelman, D. (1999). Psychology and law: An overview. In R. Roesch, S. D. Hart \& J. R. P. Ogloff (Eds.), Psychology and law: The state of the discipline (pp. 1- 20). New York, NY, USA: Kluwer Academic/ Plenum Publishers.
Ord, B., Shaw, G., \& Green, T. (2011). Investigative interviewing explained (3rd ed.). Sydney, Australia: Butterworths.

Oxburgh, G. E., \& Dando C. J. (2011). Psychology and interviewing: What direction now in our quest for reliable information? The British Journal of Forensic Practice, 13, 135-144.

Quick, B. L. \& Stephenson, M. T. (2008). Examining the role of trait reactance and sensation seeking on perceived threat, state reactance, and reactance restoration. Human Communication Research, 34, 448-476.

Redlich, A. D., Kelly, C. E., \& Miller, J. C. (2014). The who, what, and why of human intelligence gathering: Selfreported measures of interrogation methods. Applied Cognitive Psychology, 28, 817-828.

Redlich, A. D. \& Meissner, C. A. (2009). Techniques and controversies on the interrogation of suspects: The artful practice versus the scientific study. In J. Skeem, K. Douglas \& S. Lilienfeld (Eds.), Psychological science in the courtroom: Controversies and consensus (pp. 124148). New York, NY, USA: Guilford Publications.

Shepherd, E. (2007). Investigative interviewing: The conversation management approach. Oxford, United Kingdom: Oxford University Press.

Silvia, P. J. (2005). Deflecting reactance: The role of similarity in increasing compliance and reducing resistance. Basic and Applied Social Psychology, 27, 277-284.

Soukara, S., Bull, R., Vrij, A., Turner, M., \& Cherryman, J. (2009). What really happens in police interviews of suspects? Tactics and confessions. Psychology, Crime \& Law, 15, 493-506.

Stephenson, G. M. \& Moston, S. J. (1993). Attitudes and assumptions of police officers when questioning criminal suspects. Issues in Criminological \& Legal Psychology, $18,30-36$.

Štirn, M. \& Podvršič, I. (2003). Zbiranje obvestil od osumljencev [Gathering information from a suspect]. Unpublished manuscript, Ministry of the Interior, Ljubljana, Slovenia.

Sullivan, T. P. (2004). Police experiences with recording custodial interrogations. Chicago, IL, USA: Northwestern University School of Law, Center on Wrongful Convictions.

Sullivan, T. P., Vail, A. W., \& Anderson, H. W. (2008). The case for recording police interrogation. Litigation, 34(3), 1-8.

Tickle-Degnen, L., \& Rosenthal, R. (1990). The nature of rapport and its nonverbal correlates. Psychological Inquiry, 1, 285-293.

Vanderhallen, M. \& Vervaeke, G. (2014). Between investigator and suspect: The role of working alliance in investigative interviewing. In R. Bull (Ed.), Investigative Interviewing (pp. 63-90). New York, NY: Springer.

Vanderhallen, M., Vervaeke, G., \& Holmberg, U. (2011). Witness and suspect perceptions of working alliance and interviewing style. Journal of Investigative Psychology and Offender Profiling, 8, 110-130.

Vrij, A. (2008). Detecting lies and deceit: Pitfalls and opportunities. Chichester, United Kingdom: John Wiley $\&$ Sons. 
Walsh, D. \& Bull, R. (2012). How do interviewers attempt to overcome suspects' denials? Psychiatry, Psychology \& Law, 19, 151-168.

Walsh, D. \& Bull, R. (2013). The investigation and investigative interviewing of benefit fraud suspects in the UK: Historical and contemporary perspectives. In B. Cooper, D. Griesel, \& M. Ternes (Eds.), Applied issues in investigative interviewing, eyewitness memory, and credibility assessment (pp. 33-58). New York, NY, USA: Springer.

Walsh, D. \& Milne, R. (2007). Perceptions of benefit fraud staff in the UK: Giving P.e.a.c.e. a chance? Public Administration, 85, 525-540.

Walsh, D., Redlich, A. Oxburgh, G., \& Myklebust, T. (2016). Interview and interrogations of suspects: Obtaining the truth, not just confessions. In D. Walsh, G. Oxburgh, A. Redlich, \& T. Myklebust (Eds.), International developments and practices in investigative interviewing and interrogation: Vol. 2. Suspects (pp. 267-270). London, United Kingdom: Routledge.

Wedekind, C. \& Milinski, M. (2000). Cooperation through image scoring in humans. Science, 288, 850-852.

White, W. S. \& Kamisar, Y. (1981). Police interrogation and confessions: Essays in law and policy. University of Pennsylvania Law Review, 129, 994-1005.

Williamson, T., Milne, B., \& Savage, S. P. (2009). International developments in investigative interviewing. Cullompton, United Kingdom: Willan Publishing.

Zimbardo, P. G. (2007). The Lucifer effect: Understanding how good people turn evil. New York, NY, USA: Random House. 